\title{
De-mythologising the Image of War Hero as Dominant Hegemonic Masculinity Constructed through ISAs, Covert Educational Institutions (With Special Reference to David Rabe's Sticks and Bones)
}

\author{
ROYA YAGHOUBI \\ Central Tehran Branch, Islamic Azad University, Iran
}

\begin{abstract}
This paper analyses how de-mythologising the image of the war hero as that of dominant hegemonic masculinity is staged in David Rabe's play, Sticks and Bones (1969). It takes into consideration Louis Althusser's views of ISAs (Ideological States Apparatuses) which act as covert educational institutions promulgating a theory of hegemonic masculinity as being reliant upon social discourses and gender construction. Hegemonic masculinity originates from the social and cultural settings and includes defining characteristics such as chauvinism, violence, aggression, and mental and physical strength or toughness. Family, popular culture and media, as indirect educational organisations, create systems of ideas and values. The influence of these covert educational institutions is noteworthy in Sticks and Bones. In Sticks and Bones, male subjects are depicted as figures who are trained to act according to the dominant discourse and a set of masculine traits attributed to traditional macho male roles such as soldiering, going to war, and being aggressive, violent and dominant. These attempts are in vain and ineffective since the myth of American values concerning manliness is put into question or subverted in this play.
\end{abstract}

\section{Keywords}

de-mythologising, dominant hegemonic masculinity, Ideological States Apparatuses (ISAs), covert educational institutions, sticks and bones

\section{Introductory Remarks}

The image of the war hero as that of hegemonic masculinity can be observed in the media-driven discourses and screen plays. David Rabe's The Vietnam Trilogy: Sticks and Bones (1971), The Basic Training of Pavlo Hummel (1972) and Streamers (1976) are categorised as Vietnam War dramas even though the war itself is not focused on in them. In these plays, it is portrayed that ideological state apparatuses act as educational institutions manipulating male subjects to believe that war is a path to manhood. Through his dramatic work, Rabe starts to revitalise society, giving wide awareness about false ideas and principles regarding the Vietnam War and 'the dehumanising impact of an increasingly macho ethic' (Adler 1988: 112). Rabe's Vietnam plays are about men in war and the consequences that the survivors and their society encounter. These plays depict characters who in their search for manhood turn to the army. With regard to their conception of hegemonic masculinity, 
soldiering is vital for them. Rabe concentrates on the military to show the popular idea of it as being an institution which makes men rather than being an institution for war. Rabe's male characters seem mainly to be searching for macho male identity according to whatever they have learnt about manliness in the myths represented by popular culture or in the broadest sense by educational institutions.

Sticks and Bones (1969), a black comedy, is one of the plays David Rabe wrote about the Vietnam War and its outcomes. It is a family play rather than one set in the barracks. The play delineates how covert educational institutions such as family and media encourage individuals to involve themselves in a futile and destructive war as an expression of their manhood. The play opens with a slide show of family pictures on a dark stage. Offstage, voices of an adult couple are heard who in the darkness provide explanation about the people who appear on the screen to their children. In a flash forward to the final scene of the play, David's slide is shown with 'a stricken look' (Rabe 1993: 96). David's picture is interpreted as 'somebody sick' (Rabe 1993,: 96). It takes the length of the entire play to reveal what that sickness means.

David is a blind veteran who has returned home to a spiritually blind and archetypical American family that cannot accept him and wishes he were dead. The characters are based on figures from a popular television sitcom family of the 1950s and 1960s, The Adventures of Ozzie and Harriet. David's family does not succeed in sustaining the normal version of American family life, and their home becomes a place of anxiety, violence and cruelty. This failure makes them try to ignore David's 'blindness, his bizarre behaviour and what they take to be the virus of an alien experience' (Bigsby 1985: 263). They reject David since he is unable to conform to their expected model of behaviour.

In a flashback, the scene displays David's parents, Ozzie and Harriet, as typical Americans with two sons, David and Rick. But when David returns from the Vietnam War blind and emotionally numb, he proves an embarrassment to his family, especially when he keeps talking to a ghost-like Vietnamese girl. Not knowing what else to do with David, Rick, Ozzie and Harriet convince him to commit suicide. Through picturing a war hero rejected by his family, the play demythologises the belief that fighting in a war is a manly and heroic deed.

\section{Hegemonic Masculinity}

R. W. Connell first introduced Hegemonic masculinity to sociologists in 1987. This term was applied to assumptions and beliefs about masculinity that ensures the dominance of some men within the gender system. Homosexuals, women, black men, working class men or effeminate men are subordinated 
to dominant hegemonic masculinity or excluded from its realm. Overall, research on hegemonic masculinity aims at identifying those types of men who have power and authority of any kind. Furthermore, it explains how social relationships which allow some men dominance and superiority appear to be legitimate and unquestioned. Masculine hegemony is shaped in popular culture. It 'is formed from the people's common sense by; perhaps above all, television, film, advertising and sport as relayed to and received by huge audiences. Media can, though, also help to create and bolster the audience's common sense' (MacKinnon 2003: 9-10). Hegemonic masculinity is continuously renegotiated within the ever changing contemporary social and cultural structure.

\section{Dominative Hegemonic Masculinity as Ideology}

'The process of shaping and moulding' is important because 'we live in an age of mass communication, where the way we represent things becomes much more significant' (Eaglestone 2002: 117). Louis Althusser (1918-1990) argues that individuals behave considering the dominant ideology which is prescribed to them through the Ideological States Apparatuses [ISAs].

A dominant system of ideology is normally projected by the ruling class as the common-sense view of things and is accepted by the other classes. Thus, the interests of the dominant class are secured. Hegemony is related to the world-view or class-outlook of the created culture of the dominant class and the resulting ideology which makes everybody feel that all of us are freely choosing what is actually imposed on us. This is a way of manufacturing consensus through immobile forms of social control such as media, the educational system, religious institutions, art and literature that mould our ideas and attitudes.

The Vietnam Trilogy reveals how hegemonic masculinity as ideology is shaped and constructed by ISAs, organisations that create systems of ideas and values such as religious institutions, the family and media. Fiske remarks that according to Althusser 'we are all constituted as subject-in-ideology by the ISAs, that the ideological norms naturalised in their practices constitute not only the sense of the world for us, but also our sense of ourselves, our sense of identity, and our sense of relations to other people and to society in general' (eds. Rivkin \& Ryan 2004: 1270). It is useful to find 'how masculinity is constructed by various programmes in various media and then 'sold' to viewers....' (MacKinnon 2003: 33-34).

\section{Myth of Military as an institution to make man, War and Soldiering}

The myth of regimented military of America has fascinated young males in various historical eras. Through fighting in the war they believe they can 
protect and defend their families and their country. Furthermore, war makes them feel valiant and courageous. Going or refusing to go to the war displays their masculinity. According to the American masculine ethos if they go to the war it means that they are brave and gallant, but if not then they are cowards. For men, the battlefield is the ground on which to prove their manhood. The military setting has also fascinated Rabe's male characters. They risk their lives in the war to achieve masculine power and supremacy which military promises to deliver.

\section{Unseen Ideological Forces as Covert Educational Institutions and Dominant Hegemonic Masculinity}

Luis Althusser's notion of the ideological states apparatuses considers 'ideology to be a representation of the imaginary relationship of individuals to their real conditions of existence' (2004: 294). ISAs are institutions that produce ideologies that individuals adopt and later act out in behaviour. These ISAs include schools, religions, family, legal systems, politics, arts, media - organisations that create systems of ideas and values. In Sticks and Bones, family, magazine and most importantly TV are presented as the media and covert educational institutions that impose the dominant ideology of hegemonic masculinity so destructively on the male subjects. Ideological state apparatuses such as film projector, magazine, TV and most importantly family, act as discursive educational institutions and shape the popular culture and give expression to American ideology.

\section{Media and Popular Culture}

In Sticks and Bones, the typical American family takes time out from its absorption in television and magazines to observe their son, David, slit his wrists. Throughout the play, TV is focused on as a critical and educational medium of ideology. Ozzie 'becomes reinscribed in the system of identification beyond which he cannot see' (McDonough 1997: 111). At certain moments, Ozzie becomes frustrated and intolerant of his home situation. He tries to watch TV but it is not working or not introducing the false ideals anymore. In this context, TV serves as an apparatus that inculcates beliefs in the minds of the family members.

David is blinded and has no physical vision to view the dominant culture represented by TV. Juxtaposing the impaired TV as a visual educational device with David's blindness may imply the falsity of the values it has represented to the family for many years. Ozzie becomes disappointed since his lifelong values and opinions concerning the machismo image of a soldier is disapproved. Thus, he attempts to repair the TV -- which symbolically suggests that he wishes to bring everything to the normal condition. 'Profound mistrust of the media pervades Sticks and Bones: Rabe attacks the 
'instant culture' generated by television, comic books, popular magazines. ...' (Cooper 2005: 262).

The names Rabe uses for his characters are cliché since they are taken from a television situation comedy. They imply the trite values and outlook of the archetypal American family and the triteness of television itself. Indeed, depicting these characters, Rabe criticises the ideology of American society concerning the image of a happy and perfect family. Sticks and Bones foregrounds the media images of identity while contrasting these images with a real family.

It is noteworthy that David is brought first into the TV room. The room is described for him in terms of its essential feature. TV as a medium substitute for human communication. When David begins to behave weirdly in the house as an intruder, Ozzie tries anxiously to mend the broken set. Emblematically, the TV's breakdown indicates David's moral attitude against the values it presents to people. In Act II, as a conqueror David has power over other members of the family and Ozzie feels that David is going to dethrone him. To protect himself he wildly rushes to the TV since if it works, then the values it represents to American families may be revived. 'David's assault on his family and his gradual usurpation of the father-role from Ozzie drain the television set of its symbolic potency, weakening its ability to impose stereotypical values on the household' (Cooper 2005: 262).

As the covert educational medium, the television sets values through its advertisements. Both Ozzie and Harriet use the language of advertising that shows how much they are under the influence of advertisement. David's blindness and his relationship with his family are employed as mechanisms for examining American values, ethos and assumptions concerning the concept of war hero and masculinity.

A magazine serves as another covert educational medium for imposing the dominant ideology as it is represented in the play. When Harriet and Ozzie ask the priest, Father Donald, to assist them, he enters David's room with a magazine in his hand to talk with him and bless him. The magazine has an article about veterans returning from Vietnam War with PVS illness, caused by sexual relations with whores of an alien race. Father Donald believes he can acquire a kind of authority other than the spiritual one through the psychological magazine which advertises racist discrimination. But David strikes his arm, leg and head repeatedly with his cane and forces him to leave his room. Father Donald tells him that 'A man who hits a priest is in despair! ... Death! Death is your choice....' (Rabe 1993: 147-48). His statement regarding death as David's choice foreshadows the imminent death of David as the final choice. Magazine and TV play major roles in the play in 
development of the image of a true hero and ideologies about race, war, masculinities and families.

\section{Emasculation, Effeminacy as threats to the Performance of Hegemonic Masculinity in the Stereotypical Family}

In Sticks and Bones, emasculation and effeminacy act as threats to the performance of dominant hegemonic masculinity in the stereotypical family. In this play, family as a microcosm exemplifies the American ethos and values. Ignorant about the consequences, David's family encourages him to join the army. David's family plays a significant and covert educational role in the formation of his male identity. David's stereotypical parents are unwilling to let go of their beliefs with regard to the wholesomeness of American ideals, army service and soldiering, yet they do not dare to face the consequences of joining the army.

David is delivered 'like a parcel' (Rabe 1993: 102) to his family, and the Sergeant Major inquires who is the father, but it seems that Ozzie evades himself. Ozzie's reaction reminds us of the image of absent father in Rabe's other plays. Even though he is there, he desires to vanish from the house. David feels the family to which he is joining is not the family he has departed. David cries out 'Noooooooo....Sergeant...; there's something wrong here; ... I don't know these people' (104).

In Sticks and Bones, the realm of masculinity is threatened and put into crisis with the entrance of David who strikes out with his cane. Harriet accuses her husband of teaching David harmful ideals regarding 'sports and fighting' (Rabe 1993: 105). Then Ozzie talks about war, honour and blindness. Precisely, he expresses his expectations and that everything happens is completely the opposite of what he expected. Ozzie is even unhappy that David is his son: 'What does it mean that he is my son? How the hell is it that?' (Rabe 1993: 118).

Ozzie is concerned about the possibility of any threat to his realm of manhood so he tries to verify his own hegemonic masculinity. In six soliloquies, his quest for acquiring authority as an ideal man and father is noticeable. McDonald argues these soliloquies are about being a runner, playing a guitar, finding himself through Harriet, discovering 'no sign or trace' of himself, being of no use to the family, and contemplating his 'commercial on the value of Ozzie'. (1986: 220). Ozzie is always completely defeated in performing his masculine role. He is '(looking about the room like a man in deep water looking for something to keep him afloat ...)' (Rabe 1993: 115).

The connection between the violence of war and the American ethos of rivalry and violence, inculcated in the early years of boyhood, is apparent in this 
play. Ozzie explains how David behaved violently in his childhood when he 'put a knife through the skin of a cat' and 'cut the belly open' (Rabe 1993: 105). But the fullest manifestation of violence and brutality can be found in Rick who horrifyingly uses his guitar as a weapon to attack David and, later on, encourages him to commit suicide.

In Sticks and Bones, playing guitar and singing symbolically denote masculine power. In Act I, David fights with Rick and finally grabs the guitar which emblematically indicates Rick's emasculation by David. Dominant in his position, David plays guitar and narrates war traumatic happenings. Ozzie objects and David waves his cane which almost hits Ozzie. Ozzie's figurative emasculation becomes evident when he expresses his fear to Harriet: 'Do you know when he was waving that cane ...? I couldn't breathe' (Rabe 1993: 129).

Later, David expresses his hatred toward his father and his wish that Rick were dead. David tells Ozzie why he has bought this house which resembles 'a coffin' (Rabe 1993: 152). David's statement indicates that the house which is supposed to be the safety and comfort place to David is actually his coffin.

Undergoing emasculation by David and to protect his masculine strength, Ozzie calls police. Ozzie's failure becomes evident when he turns to the audience and says 'I ended up in goddamn Depression ...' (Rabe 1993: 132). Then he asks Rick to teach him how to play the guitar to reestablish his lost hegemonic dominance. His strong indignation in the loss of his true manhood is manifested in his dream. He says he had 'a dream of the guitar as huge as a building' (Rabe 1993: 162).

Thinking that he has lost to David, Ozzie roars down at David and slaps him with one hand over and over. In Act II, Ozzie apologises to David and states his misery: 'there's no evidence in the world of me- no sign or trace, as if everything I've ever done were no more than smoke. My life has closed behind me like water. ... I break on the bone. I am ...lonely' (Rabe 1993: 151). It is implied that Ozzie's bone has been broken by a stick which might be David's cane or power, which leads to Ozzie's emasculation.

Rummaging in David's stuff, Ozzie has found a cap with razors sewn inside. He asks David about its use and David tells that it is 'to cut people. ... In time I'll show you some things. ... I will be your father. (Tossing the cap at OZZIE)' (Rabe 1993: 152-53). Throwing the hat to his father, David intends to dethrone his father and replace him.

Emasculation of Ozzie is portrayed in another scene when somebody throws an egg at him while walking down the street. Ozzie feels bitter and accuses David to have thrown the egg at him. Although Ozzie and David dispute, Harriet is happy 'to hear men's voice in the house again' (Rabe 1993: 159). 
Ozzie's intensified effeminacy is delineated by his fear, vulnerability and feebleness. Having lost his supremacy at home, he confesses to David that he is afraid of his family. He believes he is 'beguiled and deceived' giving his family 'the love that was to return in time as flesh to imprison, detain, disarm and begin ... to kill' (Rabe 1993: 159).

Near to the end of the play, in a long soliloquy, Ozzie is deftly staged as a man who arrogantly addresses three pieces of furniture as his family members for self-assertion. He calls the large chair as Harriet, second chair as David and the footstool as Ricky. This metaphorical scene is very noteworthy indicating how much Ozzie's pride as a man has been shattered and the extent he desires to be obeyed by his family. Confessing that he is going to experience a downfall, a demise to his masculine power and authority, he introduces his whole property as a resolution. At least for a moment he can fancy his family as a part of his property to recover from emasculation or effeminacy. Ozzie's mirage is pricked with Harriet's voice who says she is not feeling well since crazy David has poked her with his cane. Worried and vexed, Ozzie and Harriet kneel and pray.

The fight is complete when '( a downstairs closet door burst open, and DAVID steps out, dressed in ragged combat fatigues)' (Rabe 1993: 168). David calls his mother garbage and filth and tells his father that he has to get her back if he wishes to live. Ozzie is troubled: 'I don't want to disappear. ... I will be blind. I will disappear' (Rabe 1993: 170). Rick savagely smashes his guitar down upon David saying 'we hate you' (Rabe 1993: 171). Guitar is used by Rick as the tool of violence. At last, in the fear of emasculation by David and attaining effeminate traits, Ozzie and Rick push David to cut his wrists. Female masculinity is shown in the character of Harriet who persuades David to slit his wrists: 'Go ahead ... You don't have to be afraid. ...' (Rabe 1993: 173). Apparently, alienated David first cuts one of his wrists and then the other one. The final lines of the play tell us that the family, feeling the sense of relief, rejoices. Robert Skloot (as cited in Altwein 2008: 71) states that David's suicide is 'an American exorcism, destructive of both family and myth'.

\section{Demythologising the Image of War Hero as Dominant Hegemonic Masculinity Constructed through Covert Educational Institutions}

The myth of the war hero as symbolic of hegemonic masculinity represented through covert institutional institutions is subverted in Sticks and Bones. According to the deep-seated beliefs of David's family, joining the army was supposed to make him a hero. David's photograph is seen at the beginning and the end of the play as 'somebody sick' (Rabe 1993: 96 and 175). It reminds us of what David says to his parents in Act I: 'a young ... blind man ... in a house in the dark, raising nothing in a gesture of no meaning toward two voices who are not speaking of a certain ... incredible ... CONNECTION!' 
(Rabe 1993: 127). As opposed to David's inner insight, the family members' inner blindness leads David to despair, emptiness and death. David is not rewarded for his courage, devotion and self-sacrifice in the war instead he is tremendously blamed, punished and finally murdered by his family. At the end of Act I, David tells Zung, his ghost-like Asian girlfriend, that his family has misled him to nothingness: 'I did as they told; ... and now I know that I am not awake but asleep, and in my sleep ... there is nothing ...!' (Rabe 1993: 138). Between David's delivery to his family and his suicidal action, his family discloses shallow materialistic ideals that stand in contrast to American images of the war hero.

\section{Conclusion}

Briefly speaking, both at the end of Act I and Act II of Sticks and Bones, Rabe skilfully stages how the image of the war hero as a heroic macho male represented by covert educational institutions like family and media is subverted and de-mythologised in the western world. In this play, emasculation, effeminacy and female masculinity are portrayed as threats to the performance of dominating hegemonic masculinity in the stereotypical family. Reversion of the myths of the war hero as dominative hegemonic masculinity is deftly depicted at the final distressing scene of the play when David's family encourage him to slit his wrists and commit suicide. Faced with an irresolvable problem, David chooses to end his life. The play ends with David's defeat in usurping his father's authority and proving himself as a macho male hero. The final stage direction implies that Ozzie and Ricky are victorious men at the house '(And RICK, sitting, begins to play his guitar for DAVID, and the music is alive and fast. It has a rhythm, a drive of happiness that is contagious. The lights slowly fade to black)' (Rabe 1993: 175) which ironically represents the failure of their own ideals regarding the image of the macho male.

\section{References}

Adler, T. P. (1988) South Central Review, vol. 5, no. 2, pp. 111-13. Available at: http://www.jstore.org/stable/3189585 [accessed 31 March 2011].

Althusser, L. (2004) Ideology and Ideological State Apparatuses, in Literary Theory: An Anthology. Rivkin, J. and Ryan, M. (eds.). Maiden, Blackwell Publishers Inc., pp. 693-702.

Altwein, S. (2008) The Quest for American Manhood: Issues of Race and Gender in David Rabe's Vietnam Trilogy. Saarbrucken, VDM Verlag Dr. Muller Aktiengesllschaft \& Co. 
Bigsby, C. W. E. (1985) A Critical Introduction to Twentieth-Century American Drama, vol. 3. United Kingdom, Cambridge.

Cooper, P. (2005) David Rabe's Sticks and Bones: The Adventures of Ozzie and Harriet. In Hunter, J (ed.) Contemporary Literary Criticism, vol. 200, Farmington Hills, MI: Thomson Gale, pp. 261-67.

Demastes, W. (1988) David Rabe's Assault on Rationalism and Naturalism, in Beyond Naturalism: A New Realism in American Theatre, Westport. Connecticut, Greenwood Press, PP. 35-65.

Eaglestone, R. (2002) Doing English: A Guide for Literature Students. New York, Taylor \& Francis e-Library.

MacKinnon, K. (2003) Representing Men: Maleness and Masculinity in the Media. London, Arnold Publishers.

McDonald, D. (1986) The Mystification of Vietnam: David Rabe's Sticks and Bones, Cultural Critique: American Representations of Vietnam, no. 3, pp. 211-34. University of Minnesota Press. http://www.jstor.org/stable/1354174 [accessed: 31 March 2011].

McDonough, C. (1997) David Rabe: Men under Fire, Staging Masculinity: Male Identity in Contemporary American Drama. North Carolina, McFarland and Co. Publishers, pp.103-32.

Rabe, D. (1993) The Vietnam Plays, Volume One: The Basic Training of Pavlo Hummel and Sticks and Bones. New York, Grove Press.

Thomson, E. (ed.) (2001) Drama for Students, vol. 13. Farmington Hills, MI, Gale Group.

Werner, C. (1978). Primal Screams and Nonsense Rhymes: David Rabe's Revolt, Educational Theatre Journal, vol. 30, no. 4, pp. 517-29. The John Hopkins University Press. Available at: http://www.jstore.org/stable/3206047 [accessed: 31 March 2011] 